\title{
消費者ニーズに応じたチキンエキス機能性ジペプチドの精製
}

\author{
柳内延也
}

柬海物産株式会社干101-0032 東京都干代田区岩本仃 1-10-5

\section{Purification of Antioxidative Dipeptides from Chicken Extract for Consumer's Needs}

\begin{abstract}
Nobuya Yanai
Tokai Bussan Co. Ltd., 10-5, 1-Chome Iwamoto-cho, Chiyoda-ku, Tokyo 101-0032, Japan

The functional dipeptides, Anserine and Carnosine (AC) , which are contained in chicken extract, have a specific antioxidant activity different from other botanical antioxidants such as vitamin $\mathrm{C}$, vitamin $\mathrm{E}$, carotenoids and phenolic compounds. When these antioxidants were assayed as a preventive effect on protein degradation by reactive oxygen species (ROS) , AC, Vitamin $\mathrm{C}$ and other botanical antioxidants show a preventive activity on the protein degradation by $\mathrm{ClO}$, $\mathrm{ONOO}$ and $\mathrm{OH}$ radicals, respectively. Furthermore, it is suggested that intalke of $\mathrm{AC}$ in combination with these different type of antioxidants might be more effective to prevent a harmful damage induced by ROS in vivo. In order to use $\mathrm{AC}$ for various kinds of food, we have prepared a variety of $\mathrm{AC}$ materials of different grade of purity by using membrane technology and ion-exchange chromatography. In clinical study, a soft drink contained with purified $\mathrm{AC}$, Vitamin $\mathrm{C}$ and Ferulic acid reduced serum levels of total cholesterol, triglyceride, and LDL as well as fasted glu-
\end{abstract} cose concentration in normal volunteers.

Key words : chicken extract / anserine / carnosine / antioxidants / clinical study

はじめに

チキンエキスの中には動物生体保蓝作朋を持つ機 能性ジペプチドのアンセリンとカルノシン (Anserine-Carnosine, AC と略記) が多量に含まれて いる. 特にそれらの体液平衡能や抗酸化作用は植物 原料から得られる抗酸化成分にはない動物特有の特 徵を持っているり。しかし一般に動物エキスを食品に 応用する場合にはその用途が限定され，例えばチキ ンエキスならラーメンのだしやスープ，シチューの ベースが主な用途となる。そこでこれらの機能性ジ ペプチドを広い筑国の食品に応用したり，また多く の消留者に利用できる糸材とするために任意の䊶度 に精製して機能性成分を源縮したり，チキンエキス の貭味を保持してアレルゲン性を低下させることな どが求められる。筆者らはチキンエキス中の ACを各 種万過膜処理とイオン交撸樹脂を併用して AC 含量を
調節したチキンエキス鹠品を開発してきた、本稿で はその雔品を紹介したい。

\section{1. 各種 $\mathrm{AC}$ 含有チキンエキス製品}

動物生体組織に存在する遊就アミノ酸の中で $\beta$ ーア ラニンとヒスチジンで櫡成されるジペプチドである アンセリンとカルノシンの含有量が菛も高い。内臟

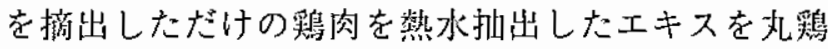
エキスと呼ぶが，その中にアンセリンとカルノシン は含有比率 $2 \sim 3: 1$ の割合でエキス固形分当たり 5 〜 $10 \%$ 含まれる。，その他の成分は遊離アミノ酸，蛋 白質，脂肪，力リウムやナトリウムなどの塩糞であ る、チキンエキスの $\mathrm{AC}$ 含量を增加させる精製法とし て篗者らは限外万過膜处理 (UF 处理, 分画分子量 3000）又はナノ万過膜処理（NF処理，分画分子瑟 500)，そしてイオン交換樹脂処理（強陽イオン交換 


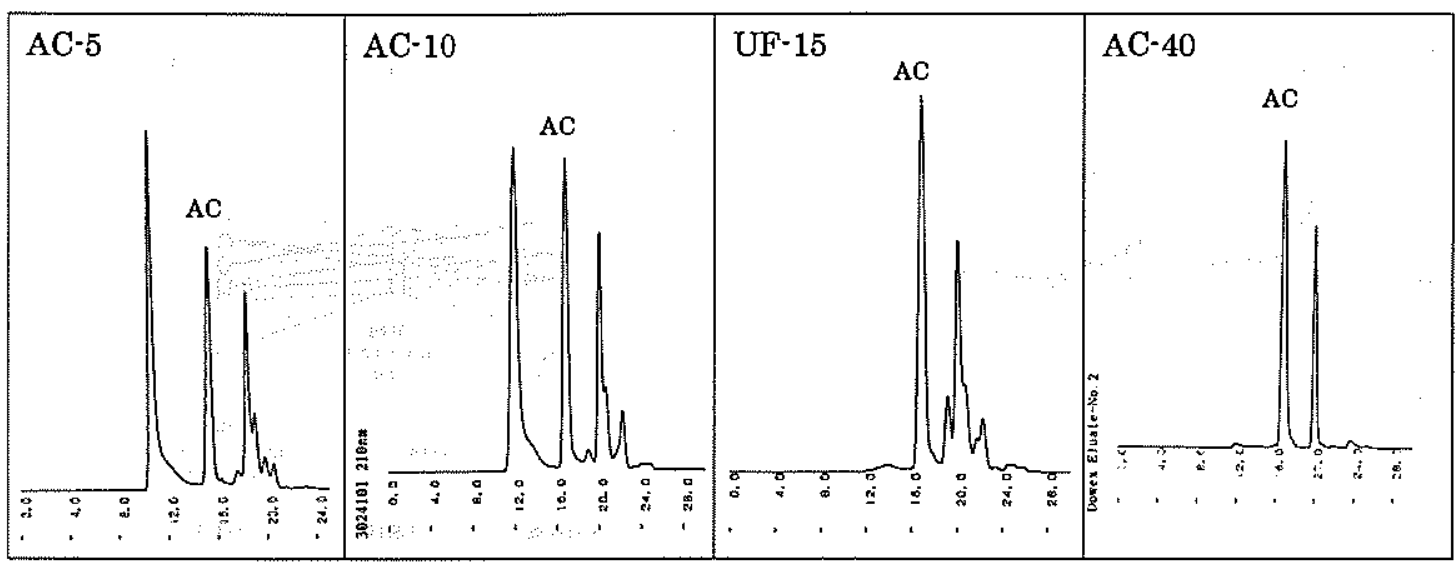

Fig. 1 GPC-HPLC profiles of various chicken extract powders.

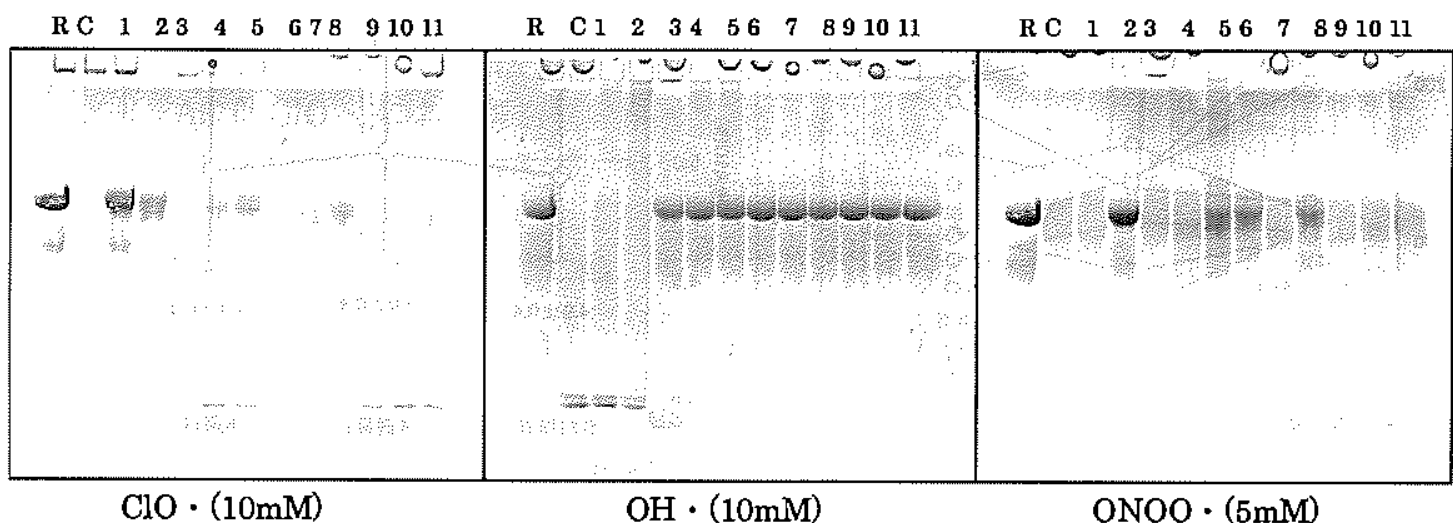

Fig. 2 Preventive effect of various antioxidants on the protein degradation by three types of reactive oxygen species, $\mathrm{ClO} \cdots, \mathrm{OH} \cdot$ and $\mathrm{ONOO} \cdot$.

$\mathrm{R}$ : Reference protein (Ovalbumin), C : Control without antioxidant, 1 : Purified AC, 2 : V.C., 3 : V.E., $4:$ Astaxanthin, $5: \beta$-carotene, $6:$ Catechin, $7:$ Quercetin, $8:$ EGCG, $9:$ Curcumin, $10:$ Chlorogenic acid, 11 : Ferulic acid.

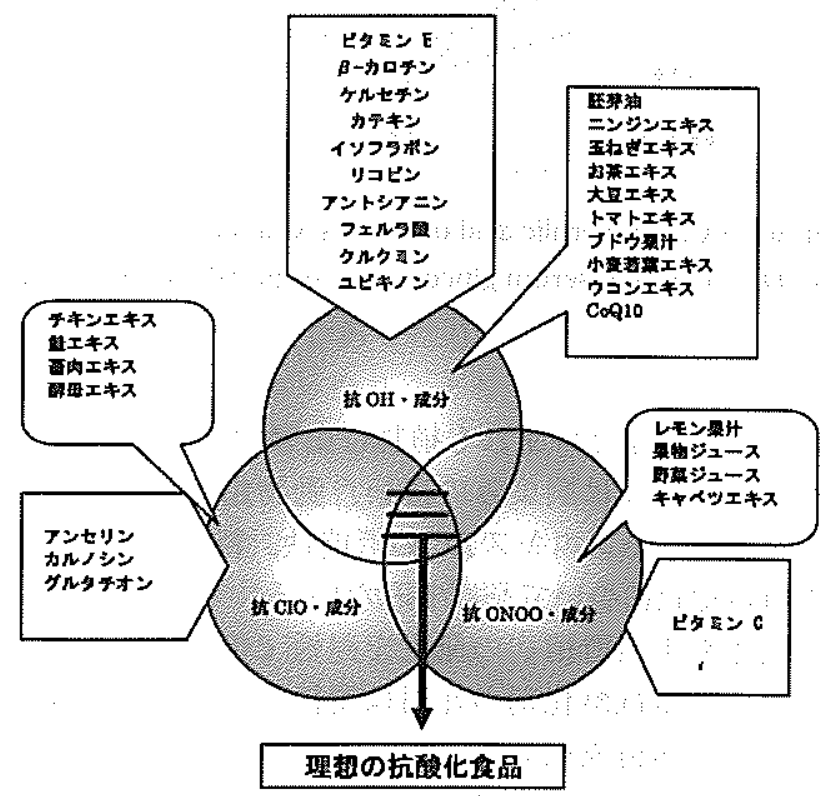

Fig. 3 Concept of ideal antioxidative foods.
体）を併用した。各処理により $\mathrm{AC}$ 含量を調整したチ キンエキスのゲルろ過-HPLCでの分子量分布 (GPCHPLC, 検出器波長 $210 \mathrm{~nm}$ ) は Fig. 1 に示寸通りであ る2!。チキンエキスは吸湿性が高いため粉末にする場 合はデキストリンなどの乾燥補助片を添加するが, それぞれAC含量を規定した粉末チキンエキス製品は AC-5 (含显 $5 \%$ ), AC-10 (含量 $10 \%$ )，UF-15（含量 10 〜 15\%)，AC-40（含量 40\%）として市販されている. 各チキンエキス轅品の特徵は, AC-5 と AC- 10 はチキ ンのコラーゲン質を残してチキンエキスのオリジナ ルな風沬を保持している，UF-15はチキンエキスの呈 味性を残してコラーゲンを含む蛋白質を完全に除去 しAC含醅を高めたものである。これはチギントル ギーの消变者でもチキンエキスの風味を堪能し譏能 性成分 $\mathrm{AC}$ を摄取できる食品素材として利用できる。 そしてAC-40はチキンエキスの風味を完全に除去し たものであり，機能性素材としてお菓子，清涼领料， 

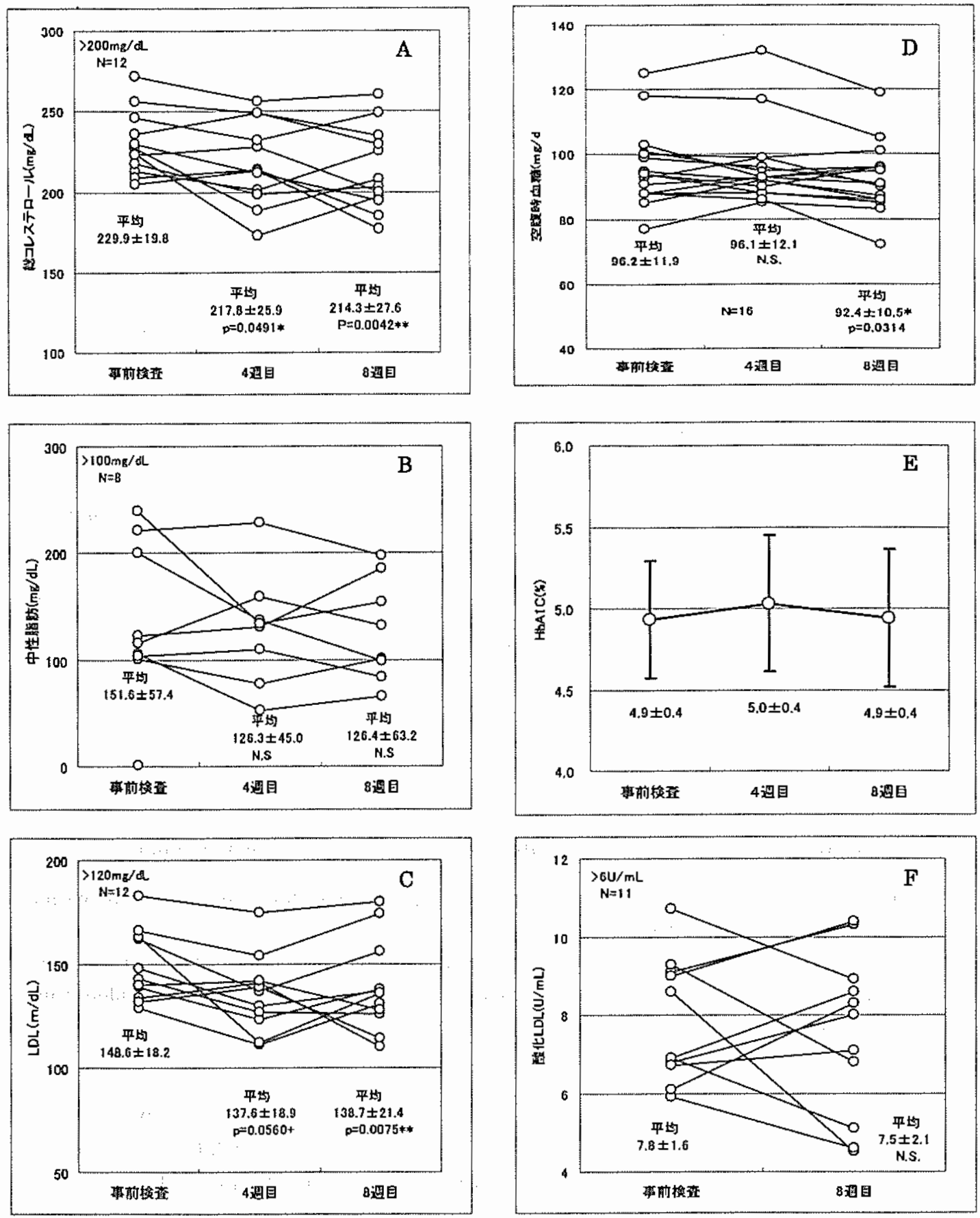

Fig. 4 Clinical effect of an antioxidative soft-drink containing purified AC, V.C. and Ferulic acid on normal volunteers.

A : serum total cholesterol, B : serum triglycerides, C : serum LDL, D : fasted serum glucose, E : serum HbAlc, F : serum oxidized LDL.

健虔食品，さらにサプリメントまであらゆるジャン ルの食品に応用が可能である。

\section{2. チキンエキスのアンセリンとカルノシン の抗酸化活性と健康機能}

健康維持に対する消热者の関心は現在，極めて高 く，抗酸化成分を含む食品類の消幽が鼠著に增加し ている：たたそれら抗酸化成分は緑墴野菜や扮茶，
大豆，果物などいる゙れも植物に的来する成分である。 そこで一般には馴染みの薄い，動物由来の抗酸化成 分であるチキンエキス $\mathrm{ACO}$ 機能性，特にその抗酸化 作用の慧莪について挙げてみたい.

老化や生活習惯病の発生を幄延・予防する效果が

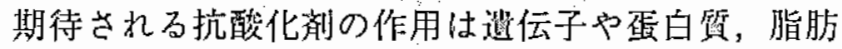
などの生体蓝成成分を伤管する活性酸素を消去する 作用にある。これら老化や組織伤管を起こす活性酸 素は生体内のエネルギー生谁の過程で必然的に生産 
されるものであり，様々な活性酸素種が存在する。 的物と植物に共通する活性酸素の発生経路は細胞内 のミトコンドリアで行なわれるエネルギー代謝であ るが，そこでは体内に取り込まれた酸素ガス $\left(\mathrm{O}_{2}\right)$ がイオン化して生じるスーパーオキサイドアニオン $\left(\mathrm{O}_{2}{ }^{-}\right)$とその派生物の過酸化水素 $\left(\mathrm{H}_{2} \mathrm{O}_{2}\right)$ である。 $\mathrm{H}_{2} \mathrm{O}_{2}$ は通常, 酵素により速や加に分解されて水と酸 素ガスになるが，鉄イオン $\left(\mathrm{Fe}^{++}\right)$などの触媒作用を 受けると水酸化ラジカル $(\mathrm{OH} \cdot)$ を発生させる。一 方，動物に特徵的な活性酸素の発生経路もある. 動 物には免疫機能を担当する白血球が存在し, 感染防 御や異物除去のためにジ亜塩素酸ラジカル（ClO・） や過酸化亚硝酸ラジカル（ONOO・）を発生させる.

椿成分子が筫なる活性酸素種を $\mathrm{OH} \cdot \mathrm{ClO} \cdot$ 及び ONOO ・の3種に分非して，これらが起こす蛋白質 分解作用に対する各種抗酸化削の抗酸化活性を $\mathrm{AC}$ と 比較してみると ${ }^{31}, \mathrm{AC}$ は $\mathrm{ClO}$ ・による蛋白質分解を 顕著に抑制する作用を有していたのに対して，植物 由来の脂溶性抗酸化剂はいずれも $\mathrm{OH}$ ・による分解 に対して強い抗酸化作用を示した。しかしCIO・や ONOO ・䇃対る抗酸化作用はこ机らが生体に存在 できる澓庤の10倍量でも発揮できなかった，一方， 水溶性のビタミンC (V.C) は OH・ に対して殆ど抗 酸化作用を示さなかったが ONOO・に対して最も強 い抗酸化活性を示した（Fig. 2)。この実駘結果は動 物に由来する ACが動物だけが生産する白血球起源の 塩素系活性酸糸に対する抗酸化作用を持つことを強 く示唆するものである。

\section{3. チキンエキスを主要成分とする抗酸化飲 料の臨床成績}

加龄に伴って起こる動脈硬化，简脂血症，高血糖， 更に細胞変性による瀶の発生はいずれも活性酸素の 伤害が体内に落皘されて発症すると考えられるが, それは酸化脂筑や酸化ストレスで生産が促進される 最終糖化産物の血管内落積であったり，肝臟での脂 肪代謝機能の低下であったり，䑏荿でのインシュリ ン生産の低下であったり，そして遗伝子DNAの储害 であったりするためである。これらの酸化障害が例 えば OH・単独の活性酸素で起こっているのではな いとすれば，動物である私遠には白血球に时来する 活性酸素に対する抗酸化削の掑取が必要であり，少 なくとも上記の 3 種の活性酸素を抑制する抗酸化剤を 配合した食品が活性酸琹によって起こる老化, 生活
習㥧病の予防には有効であると考えられる。

そこでチキンエキスより精製した AC $(400 \mathrm{mg}$ ， $\mathrm{ClO}$ ・消去剂）と米棣から精製されたフェノール化 合物のフェルラ酸 ( $20 \mathrm{mg}, \mathrm{OH} \cdot$ 消去剂) そして V.C. (300mg, ONOO ・ 消去剂) を含有する抗酸化 性成分飲料を調制し，中高年の健常人を対象に健康 機能に及ぼす効果を試験してみた。1日1本，8週間 飲用したとき，血中総コレステロール，LDL，中性 脂肪，劦腹時血糖がいずれも低下する效果が観察さ れた。これは抗酸化成分が脂質代謝やインシュリン 分泌を直接促暹した作用ではなく，脂質代謝やイン シュリン分泌を行なう細胞組織の酸化障害による機 能低下を防止したために，結果として若年者のよう にコレステロールや血糖值を低下させたと考えら れた。

\section{おわりに}

多種多様な抗酸化性成分を含む食品が市販されて いるが，活性酸素の伤害作用を效果的に抑制するた めには同系統，同効の抗酸化成分を掑取するのでは なくバランスのよい抗酸化成分を撕取することが重 要である。そしてチキンエキスなど動物エキスに含 まれる抗酸化ペプチドは数少ない塩素系活性酸素に 対寸る抗酸化成分であり，この成分を動物性食品本 来の食材ではなく広い範囲の食品に利用されること が必要である，その意味で各種膜技術やイオン交換

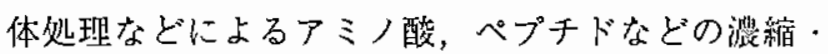
精製技術が新しい食品加工法として広く晋及するの ではないかと思われる。

\section{文藏}

1) Boldyrev $\mathrm{AA}$ and Severin $\mathrm{SE}$ : The Histidine-containing dipeptides, Carnosine and Anserine. Distribution, properties, and biological significance, Adv. Enzyme. Regul., 30 175-194 (1990)

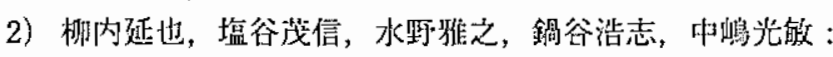
動物エキス中のヒスチジン含有ジペブチド（アンセり

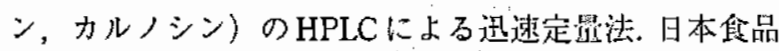
科学工学会訨, 51 33-37 (2004)

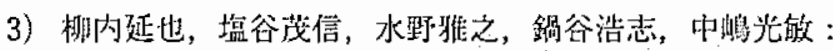
チキンエキス由来アンセリンーカルノシン混合体の抗酸

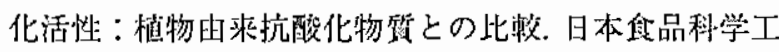
学会誌, 5I 238-246 (2004)

(Received 1 June 2005 ; Accepted 3 June 2005) 